\title{
MODULATORY ROLE OF SELENIUM AND VITAMIN E AGAINST OXIDATIVE STRESS INDUCED HEPATOTOXICITY AND NEPHROTOXICITY IN RATS EXPOSED SUB-CHRONICALLY TO HEXAVALENT CHROMIUM
}

\author{
SOMA CHOUDHURI ${ }^{1}$, JAHNABI SAHA ${ }^{2}$, SANDEEP DAS ${ }^{2}$, DIPAYAN CHOUDHURI ${ }^{2 *}$ \\ ${ }^{1}$ Department of Physiology, Tripura Medical College and Dr. B.R. Ambedkar Teaching Hospital, Hapania, Agartala, Tripura, \\ India. ${ }^{2}$ Department of Human Physiology, Tripura University (A Central University), Suryamaninagar, Agartala, Tripura, India. \\ Email: dipayanchoudhuri@gmail.com
}

Received: 13 May 2020, Revised and Accepted: 27 May 2020

\section{ABSTRACT}

Objective: The present study assessed the hepatotoxicity and nephrotoxicity associated with oxidative stress induced by chronic exposure to a very low environmentally relevant dose of hexavalent chromium along with the ameliorative potential of selenium and Vitamin E in male rats.

Methods: Twenty-four male albino rats were divided into four groups. Animals of control group received only distilled water. The treated group received solution of potassium dichromate $\left(\mathrm{K}_{2} \mathrm{Cr}_{2} \mathrm{O}_{7}\right)$ at a dose of $1 \mathrm{mg} / \mathrm{kg}$ b.w./day. The third group received sodium selenate $(0.25 \mathrm{mg} / \mathrm{kg}$ bw) plus Vitamin E $(100 \mathrm{mg} / \mathrm{kg} \mathrm{bw})$. The supplemented group received sodium selenate plus Vitamin $\mathrm{E}$ along with $\mathrm{K}_{2} \mathrm{Cr}_{2} \mathrm{O}_{7}$ solution. The animals were treated for 90 consecutive days.

Results: There was a significant decrease in body weight gain and an increase in liver and kidney weight along with an increase in serum glucose, cholesterol, urea, and creatinine; a decrease in protein and albumin levels in the rats treated with $\mathrm{K}_{2} \mathrm{Cr}_{2} \mathrm{O}_{7}$. The activities of serum enzymes, serum glutamate oxaloacetate transaminase, serum glutamate pyruvate transaminase, acid phosphatase, and alkaline phosphatase, were also increased in treated animals. The activities of enzymes catalase, superoxide dismutase, GPx and the levels of GSH reduced significantly and level of malondialdehyde increased in $\mathrm{K}_{2} \mathrm{Cr}_{2} \mathrm{O}_{7}$ treated rats. Liver and kidney tissues exhibited features of toxicity in chromium treated animals. All the effects were reversed in supplemented group.

Conclusion: Chronic exposure to $\mathrm{K}_{2} \mathrm{Cr}_{2} \mathrm{O}_{7}$ at a very low environmentally relevant dose caused hepatotoxicity and nephrotoxicity induced by oxidative stress in male albino rats; the effects were ameliorated by supplementation with selenium and Vitamin E in combination.

Keywords: Chromium, hepatotoxicity, nephrotoxicity, oxidative stress, selenium, Vitamin E.

(c) 2020 The Authors. Published by Innovare Academic Sciences Pvt Ltd. This is an open access article under the CC BY license (http://creativecommons. org/licenses/by/4. 0/) DOI: http://dx.doi.org/10.22159/ajpcr.2020.v13i8.37900

\section{INTRODUCTION}

Oral exposure to hexavalent chromium (CrVI) produces gastrointestinal, haematological, hepatic, renal and neurological defects [1]. Exposure to chromium causes damage to liver, the principal organ associated with metabolism, detoxification and secretary function in the body [2]. Long-term chronic exposure to chromium also causes renal injury and produces renal dysfunction [3]. Most of these reports were based on studies with short time exposure at very high exposure doses. However, people are generally exposed to heavy metals including chromium in the environment to a much lower dose and for a longer period. We recently observed an alteration in serum biochemical and hematological parameters in male rats due to chronic exposure to $\mathrm{Cr} \mathrm{VI}$ at an environmentally relevant dose [4]. Cr VI and its intermediates are capable of generating reactive oxygen specie (ROS), leading to oxidative stress. In addition, it reduces the antioxidant capacity by decreasing the activities of different enzyme systems associated with antioxidant defense mechanisms [5]. Chromium is reported to cause both hepatotoxicity and nephrotoxicity through oxidative stress mediated mechanism in experimental animals [6].

In recent times, different antioxidants including natural antioxidants have been evaluated for their ameliorative potential against heavy metal-induced toxicity, including chromium toxicity. Two of the widely studied antioxidants for their role in the amelioration of heavy metal-induced toxicity are micronutrient selenium (Se) and natural antioxidant Vitamin E (Vit E) in combination [7]. Se, an essential micronutrient protects the lipid membrane from oxidative damage caused by peroxidase [8]. Vit E ( $\alpha$-tocopherol) which is located in the cell membrane is one of the most important naturally occurring antioxidants acting against oxidative stress induced by heavy metals including chromium [9]. Recently their roles as antioxidants in combination have been evaluated against many toxicants including chromium [10].

In view of the above fact, the current study aimed to determine the extent of hepatotoxicity and nephrotoxicity produced by a sub-chronic exposure to a very low environmentally relevant dose of hexavalent chromium along with ameliorative potential of selenium and Vitamin E in combination against such chronic exposure.

\section{METHODS}

Chemicals

Potassium dichromate $\left(\mathrm{K}_{2} \mathrm{Cr}_{2} \mathrm{O}_{7}\right)$ obtained from Mark Specialties Pvt. Ltd. India. Commercial kits for estimation of glucose, total protein, albumin, cholesterol, urea, creatinine, serum glutamate pyruvate transaminase (SGPT) and serum glutamate oxaloacetate transaminase (SGOT) were purchased from the Coral System. Magnesium chloride, sodium hydroxide, sodium-P-nitrophenol, pnitrophenol, citric acid, and sodium citrate were obtained from Sisco Research Laboratories Pvt. Ltd.

\section{Animals}

Male albino rats (150-160 g) were used for the study. The animals were obtained from the Committee for the Purpose of Control and Supervision on Experimental Animals, Government of India, registered animal supplier. The animals were maintained in university animal house and were supplied with a standard rat food and water ad 
libitum. They were maintained in a controlled condition of temperature $\left(25 \pm 2^{\circ} \mathrm{C}\right)$ and normal day/night schedule (12L: 12D). The Institutional Animal Ethical Committee approval was obtained for the study protocol.

\section{Study design}

The animals were divided into four groups of six animals in each group. All the animals received their respective treatments orally through gavages for 90 days.

Group- I (Control group): Received distilled water $2 \mathrm{ml} /$ day.

Group-II (Chromium treated group): Received solution of $\left(\mathrm{K}_{2} \mathrm{Cr}_{2} \mathrm{O}_{7}\right)$ at a dose of $1 \mathrm{mg} / \mathrm{kg}$ body weight/day.

Group-III \{Selenium plus Vitamin E treated group\}:- Received sodium selenate $(0.25 \mathrm{mg} / \mathrm{kg}$ bw) plus Vitamin E $(100 \mathrm{mg} / \mathrm{kg} \mathrm{bw})$.

Group-IV (Supplemented group\}:- Received sodium selenate $(0.25$ $\mathrm{mg} / \mathrm{kg} \mathrm{bw}$ ) plus Vitamin E (100 mg/kg bw). Along with the solution of $\mathrm{K}_{2} \mathrm{Cr}_{2} \mathrm{O}_{7}$

The dose of $\mathrm{K}_{2} \mathrm{Cr}_{2} \mathrm{O}_{7}$, Se and Vit E were selected on the basis of the previous reports $[4,7]$.

The animals were sacrificed after completion of the treatment period by cervical dislocation under ether anesthesia following Indian Council of Medical Research guide lines [11].

\section{Body weight and organ weight}

The weight of each animal taken on the $1^{\text {st }}$ day of the experiment was considered as the initial body weight. The body weight taken on the day of sacrifice was considered as final body weight. After autopsy, the liver and kidneys were dissected out and immersed in normal saline and cleared of adherent tissues and blood vessels. The organs were blotted free of mucous, weighed, and expressed per $100 \mathrm{~g}$ body weight.

\section{Blood collection and serum separation}

The blood was collected by cardiac puncture, serum separated, collected and kept at $-20^{\circ}$ for future analysis.

\section{Preparation of liver and kidney homogenate}

The part of liver and kidney tissues were homogenized in aqueous phosphate, K2PO4/KHPO4 buffer (0.1 M; PH=7.4); in 4:1 volume of buffer to organ weight at $4^{\circ} \mathrm{C}[12]$.

\section{Analysis of serum biochemical parameters}

The serum glucose, total protein, serum albumin, cholesterol, serum urea, creatinine, SGPT and the SGOT were measured using commercial kits following manufacturers guidelines. The levels of enzymes alkaline phosphatase (ALP) and acid phosphatase (ACP) were estimated by the method of Bessey et al. [13]. Protein from liver and kidney homogenates was estimated by Bradford method [14].

\section{Assessment of oxidative stress biomarkers}

The level of lipid peroxidation and activity level of various antioxidant enzymes were measured in liver and kidney homogenates using standard methods. The malondialdehyde (MDA) concentration was determined according to the method of Ohkawa et al. [15]. The catalase (CAT) activity was determined according to the method of Aebi [16]. The superoxide dismutase (SOD) activity was determined according to the method of Marklund and Marklund [17]. The glutathione peroxidise activity was determined according to the method of Paglia and Valentine [18]. The reduced glutathione (GSH) level was determined according to the method of Ellman and Fiches [19].

\section{Histopathological analysis of liver and kidney}

The liver and kidney tissues were sliced in to small pieces and fixed in $4 \%$ formalin solution for $48 \mathrm{~h}$. The fixed organs were dehydrated in ascending series of alcohol, cleared in xylene, and embedded in paraffin wax. Then 4-5 $\mu \mathrm{m}$ thick sections of tissues were prepared by rotary microtome and stained by Harris hematoxylin and Eosin. The stained sections were observed under low power $(\times 20)$ and high power $(\times 40)$ and photomicrographs were taken for analysis.

\section{Statistical analysis}

The values were expressed as mean $\pm \mathrm{SE}$ for comparison between experimental groups. The data with normal distribution and homogeneous variance were analyzed for one-way analysis of variance (ANOVA) and " $\mathrm{t}$ " test using statistical software (SPSS 16.0), a $\mathrm{p} \leq 0.05$ was considered statistically significant.

\section{RESULTS}

\section{Effect on body weight gain and organ weight}

There was a significant reduction in percentage gain of body weight after chronic exposure to chromium (1 $\mathrm{mg} / \mathrm{kg}$ body weight/day) for 90 consecutive days. Weight of both liver and kidney was increased significantly in animals exposed to chromium (Group-II) in comparison to control animals (Group-I). These effects were nearer to control animals in Se and Vit E treated groups (Group-III); and in animals supplemented with Se and Vit E along with chromium (Group-IV) (Table 1).

\section{Effect on serum biochemical parameter}

There was a significant $(\mathrm{p}<0.01)$ increase in the levels of glucose, cholesterol, urea and creatinine and a decrease in levels of protein and albumin in the animals treated with chromium. The serum levels of SGPT and SGOT enzymes were also elevated in these animals. There was a significant increase in activities of enzymes ACP and ALP. Cotreatment with Se and Vit E reversed the conditions (Table 2).

\section{Effect on histoarchitecture of liver and kidney}

The histological picture of liver in control (Group-I), Se and Vit E treated (Group- III) and supplemented groups (Group - IV) showed normal architecture with several hepatic lobules separated from each other by connective tissue septa housing the portal triad. Each lobule contained well demarked central canal surrounded by radiating cords and separated by blood sinosoids. The animals treated with chromium (Group II) showed marked changes in architecture of liver with pronounced vacuolation and fatty degeneration in hepatocytes with congestion of central veins and sinusoids (Fig. 1). Section of kidney in Group-I (control) showed the normal appearance of glomerulus (red arrow), proximal convoluted tubules (yellow arrow), and distal convoluted tubules (green arrow). Group II (chromium treated) showed severe tubular degeneration of proximal convoluted tubules (yellow arrow) and distal convoluted tubules (green arrow), damaged glomeruli (red arrow) and with wide lumina (black arrow). Group IV showed improved renal structure such as restoration of glomerulus (red arrow), proximal convoluted tubules (yellow arrow), distal convoluted tubules (green arrow), and narrowing of lumina (black arrow) in the chromium exposed rats. Group III also showed normal renal architecture (Fig. 2).

\section{Effect on lipid peroxidation}

Levels of MDA increased significantly in both liver and kidney homogenates of chromium treated animals. Supplementation with Se and Vit $\mathrm{E}$ reduced chromium induced elevation in MDA levels in both liver and kidney (Tables 3 and 4).

\section{Effect on antioxidant enzyme system}

There was a significant decrease $(\mathrm{p}<0.01)$ in the activities of antioxidant enzymes CAT, SOD, GPx, and GSH levels in tissue homogenates of chromium treated animals.. The activities of antioxidant enzymes in liver and kidney were found to be restored to control level in supplemented animals (Tables 3 and 4).

\section{DISCUSSION}

Health hazards associated with exposure to heavy metals have been studied over the years and significant volume of data has been 
Table 1: Effect of selenium (Se) and Vitamin E (Vit E) supplementation on chromium induced changes in body weight gain, daily food consumption and relative weight of liver and kidney

\begin{tabular}{llll}
\hline Parameters & Group & & \\
\cline { 2 - 3 } & Group I & Group II & Group III \\
\hline Initial body weight (g) & $157.8 \pm 2.9$ & $162.1 \pm 2.3$ & $166.6 \pm 2.7$ \\
Final body weight (g) & $263.5 \pm 3.1$ & $243.0 \pm 5.6$ & $278.7 \pm 3.0$ \\
Body weight gain (\%) & $66.98 \pm 0.7$ & $49.90 \pm 0.6 \mathrm{a}^{* *}$ & $67.22 . \pm 0.9 \mathrm{~b} \# \mathrm{~d}^{* *}$ \\
Food consumption (g/rat/day) & $26.6 \pm 0.7$ & $23.1 \pm 0.5 \mathrm{a}^{* *}$ & $24.7 \pm 0.7 \mathrm{~b} \# \mathrm{~d}^{*}$ \\
Weight of liver (g/100g bw) & $3.82 \pm 0.2$ & $4.38 \pm 0.1 \mathrm{a}^{*}$ & $3.79 \pm 0.02 \mathrm{~b} \# \mathrm{~d}^{*}$ \\
Weight of Kidney (g/100g bw) & $0.528 \pm 0.2$ & $0.813 \pm 0.1 \mathrm{a}^{*}$ & $0.579 \pm 0.02 \mathrm{~b} \# \mathrm{~d}^{*}$ \\
\hline
\end{tabular}

Group I=Control group; Group II=Chromium treated group; Group III=Se- and Vit E treated group; Group IV=Chromium plus Se- and Vit E supplemented group.

Values are represented as mean $\pm \mathrm{SE}$; animals $(\mathrm{n})=6$ /group. $\mathrm{a}=$ Group I versus Group II; $\mathrm{b}=$ Group I versus Group III; $\mathrm{c}=\mathrm{Group}$ I versus Group IV; $\mathrm{d}=\mathrm{Group}$ II versus

Group III; e=Group II versus Group IV; f=Group III versus Group IV; ${ }^{*}=\mathrm{p}<0.05 ;{ }^{* *}=\mathrm{p}<0.01 ;{ }^{* * *}=\mathrm{p}<0.001$, \#=Non significant

Table 2: Effect of Selenium (Se) and Vitamin E (Vit E) supplementation on chromium induced changes in serum biochemical parameters

\begin{tabular}{|c|c|c|c|c|}
\hline \multirow[t]{2}{*}{ Parameters } & \multicolumn{4}{|l|}{ Group } \\
\hline & Group I & Group II & Group III & Group IV \\
\hline Serum glucose $(\mathrm{mg} / \mathrm{dl})$ & $103.4 \pm 2.0$ & $118.5 \pm 2.8 a^{* *}$ & $106.6 \pm 2.7 \mathrm{~b} \# \mathrm{~d}^{*}$ & 109.3 $\pm 2.1 \mathrm{c} \# \mathrm{e}^{* \mathrm{f} \#}$ \\
\hline Protein $(\mathrm{g} / \mathrm{dl})$ & $6.38 \pm 0.1$ & $4.73 \pm 0.1 \mathrm{a}^{* *}$ & $6.89 \pm 0.2 b \# d^{* *}$ & $7.12 \pm 0.2 \mathrm{c} \# \mathrm{e}^{* *} \mathrm{f} \#$ \\
\hline Albumin (mg/dl) & $4.79 \pm 0.1$ & $3.48 \pm 0.1 \mathrm{a}^{* *}$ & $4.21 \pm 0.1 \mathrm{~b} \# \mathrm{~d}^{* *}$ & $4.16 \pm 0.1 \mathrm{c} \# \mathrm{e}^{* *} \mathrm{f} \#$ \\
\hline Cholesterol (mg/dl) & $64.3 \pm 2.2$ & $74.1 \pm 0.9 \mathrm{a}^{* *}$ & $65.6 \pm 0.5 b \# d^{* *}$ & $67.2 \pm 1.1 \mathrm{c} \# \mathrm{e}^{* *} \mathrm{f} \#$ \\
\hline Urea (mg/dl) & $42.4 \pm 1.1$ & $54.29 \pm 1.3 \mathrm{a}^{* *}$ & $46.7 \pm 0.7 b \# d^{* *}$ & $44.3 \pm 0.8 \mathrm{c} \# \mathrm{e}^{* *} \mathrm{f} \#$ \\
\hline $\mathrm{SGOT}(\mathrm{U} / \mathrm{ml})$ & $61.80 \pm 1.4$ & $69.40 \pm 0.9 \mathrm{a}^{* *}$ & $64.42 \pm 1.0 \mathrm{~b} \# \mathrm{~d}^{* *}$ & $63.16 \pm 1.0 \mathrm{c} \# \mathrm{e}^{* *} \mathrm{f} \#$ \\
\hline SGPT $(\mathrm{U} / \mathrm{ml})$ & $52.71 \pm 1.2$ & $59.28 \pm 0.9 a^{* *}$ & $53.17 \pm 0.9 \mathrm{~b} \# \mathrm{~d}^{*}$ & $52.63 \pm 0.7 \mathrm{c} \# \mathrm{e}^{* *} \mathrm{f} \#$ \\
\hline $\operatorname{ALP}(\mathrm{U} / \mathrm{ml})$ & $5.12 \pm 0.05$ & $7.18 \pm 0.05 \mathrm{a}^{* *}$ & $5.79 \pm 0.06 \mathrm{~b} \# \mathrm{~d}^{* *}$ & $5.96 \pm 0.05 \mathrm{c} \# \mathrm{e}^{* *} \mathrm{f} \#$ \\
\hline $\mathrm{ACP}(\mathrm{U} / \mathrm{ml})$ & $2.16 \pm 0.1$ & $3.52 \pm 0.02 \mathrm{a}^{* *}$ & $2.73 \pm 0.08 \mathrm{~b} \# \mathrm{~d}^{* *}$ & $2.81 \pm 0.05 \mathrm{c} \# \mathrm{e}^{* *} \mathrm{f} \#$ \\
\hline
\end{tabular}

Group I=Control group; Group II=Chromium treated group; Group III=Se- and Vit E treated group; Group IV=Chromium plus Se- and Vit E supplemented group. Values are represented as mean $\pm \mathrm{SE}$; animals $(\mathrm{n})=6$ /group. $\mathrm{a}=$ Group I versus Group II; $\mathrm{b}=\mathrm{Group}$ I versus Group III; $\mathrm{c}=\mathrm{Group}$ I versus Group IV; $\mathrm{d}=\mathrm{Group}$ II versus Group III; e=Group II versus Group IV; $\mathrm{f}=$ Group III versus Group IV; ${ }^{*}=\mathrm{p}<0.05 ;{ }^{* *}=\mathrm{p}<0.01$; ${ }^{* * *}=\mathrm{p}<0.001$, \#=Non significant. SGOT: Serum glutamate oxaloacetate transaminase, SGPT: Serum glutamate pyruvate transaminase, ALP: Alkaline phosphatase, ACP: Acid phosphatase

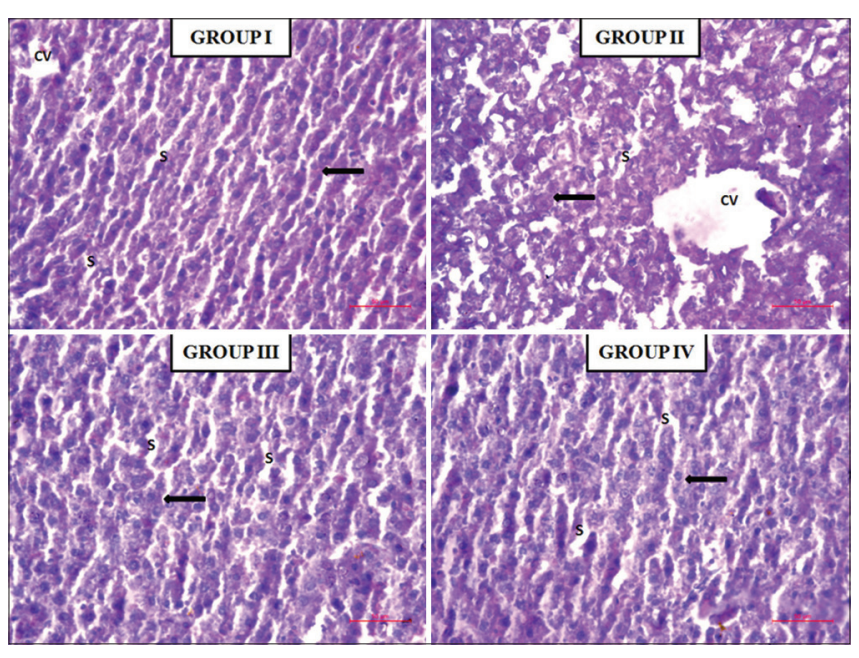

Fig. 1: Represents the histopathological analysis of liver of various groups under chromium treatment and supplementation with selenium plus Vitamin E. Group I-Control; Group II-Chromium treated; Group III-(selenium plus Vitamin E treated);

Group IV- (chromium + selenium plus Vitamin E supplemented). Histopathological examination of liver tissue was carried by hematoxylin and eosin ( $\mathrm{H}$ and $\mathrm{E}$ ) staining and the microscopic images were viewed under $\times \mathbf{4 0}$ magnification (scale bar $=\mathbf{5 0} \mu \mathrm{m}$ ). CV: Central Vein, S: Sinusoids; black arrows- indicate hepatocytes

accumulated by now on various adverse effects and their mechanisms. Consequent to this, various environmental protection regulations have been promulgated across the nations to protect living organisms against acute exposure to high levels of heavy metals. However, chronic exposure to a lower level of heavy metals through food, water and air is still common in industrial areas and continued to remain as a pertinent global problem [1]. For example, people residing near tanneries are subjected to chronic exposure to a very low level of chromium through ground water [20]. Information on health hazards of such low level chronic exposure to chromium is still scarce. Hence, the purpose of the study was to revisit hexavalent chromium (Cr VI) toxicity adopting a protocol simulating chronic oral exposure and to evaluate ameliorating potential of two widely studied antioxidants selenium and Vitamin E against such chronic exposure.

We observed a significant reduction in body weight gain in chromium treated rats. The observation is in a similar line to that of Gilbert et al. who reported long back from their epidemiological study that there was a decrease in net body weight gain in human exposed chronically to chromium [21]. There are reports from many animal studies that confirm our findings of decline in net body weight gain with exposure to chromium [22]. As observed in our study, heavy metal exposures reduce the percentage gain in body weight by mainly reducing the food efficacy [23]. There was a significant increase in weight of liver and kidney in chromium treated rats in our study. This is a common finding in heavy metal induced toxicity as both the organs are associated with metabolism and excretion of toxic substances [24]. Contrary to this, Momo et al. observed that relatively low dose longer exposure to potassium dichromate in rabbit doe did not cause significant change in anatomy of both liver and kidney [25].

Serum biochemical analysis of the study showed an increase in the concentration of glucose, total cholesterol, urea and creatinin levels with a concomitant decrease in total protein and albumin level in chromium treated rats. Both urea and creatinine are routinely evaluated as markers of renal function. Increase in urea and creatinine might be due to the dysfunction of glomerulus, structures associated with renal filtration [26]. An increase in glucose and cholesterol levels in exposed animals might be due to defects in utilization of these nutrients at the tissue level [27]. Chromium is reported to cause increase in cholesterol 
levels in cells by up regulating cholesterol synthesizing enzymes [28]. Contrary to our findings, there are reports that suggest that chromium exposure causes hypoglycemia and this may be due to conversion of hexavalent chromium to trivalent chromium-ATP complex that acts as competitive inhibitor for different ATP-dependent enzymes and several kineses involved in glycolysis [29]. Decline in the total protein and albumin can be associated with generalized reduction in protein metabolism due to general and systemic toxic effects in chromium treated rats [30]. It might be associated with reduced protein synthesis or increased proteolysis or protein degradation [31]. The decline in total protein and glycogen might be associated with generation of oxygen free radical by hexavalent chromium which oxidizes proteins and lipoproteins and impairs liver structure and metabolism [32]. A high level of serum enzymes SGOT and SGPT is indicative of liver injury

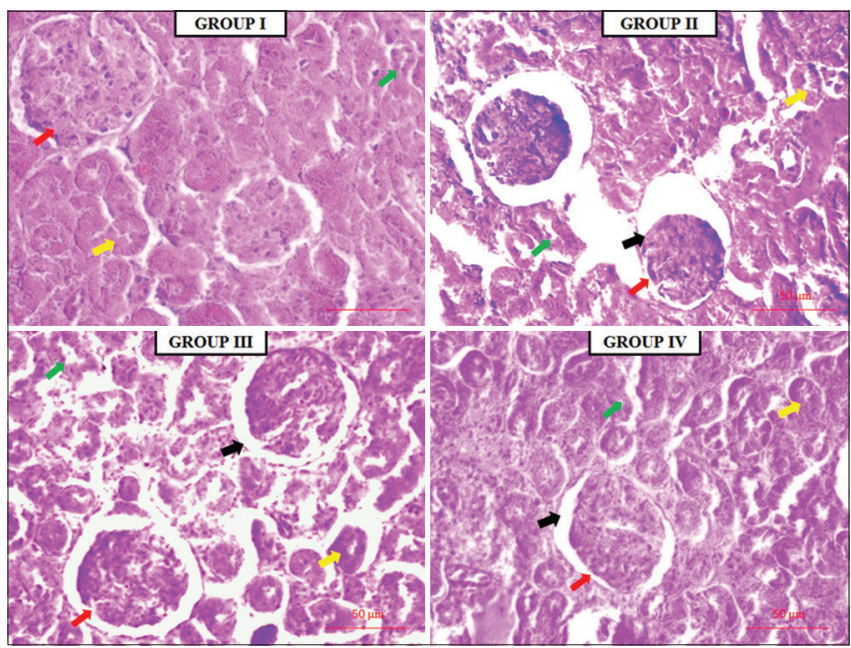

Fig. 2: Represents the histopathological analysis of kidney of various groups under chromium treatment and supplementation with selenium plus vitamin E. Group I- Control; Group II-Chromium Treated; Group III-(Selenium plus vitamin

E treated); Group IV-Chromium + Selenium plus Vitamin E supplemented. Histopathological examination of kidney tissue was carried by hematoxylin and eosin ( $\mathrm{H}$ and $\mathrm{E}$ ) staining and the microscopic images were viewed under $\times 40$ magnification (scale bar $=\mathbf{5 0} \mu \mathrm{m}$ ) and is generally associated with exposure to the heavy metal [33]. Both ACP and ALP are the sensitive biomarkers of cellular damage [34]

Cytotoxicity due to chromium exposure is clearly indicated by histopathological alterations in hepatic and renal tissues in our study. Deterioration of organization of hepatic cords with disruption of endothelial lining in sinusoids and central veins in liver sections of chromium exposed animals are indicators of hepatotoxicity [2]. Similarly, microscopic examination of kidney tissue treated with potassium dichromate showed signs of degeneration in tubular epithelial cells in form of vacuolation, congested glomerular capillaries and glomerular tufts, signs of chromium induced nephrotoxicity [3].

Disruption of serum biochemical profile specially the levels of toxicological marker enzymes suggested that chronic exposure to chromium might have generated ROS, thus causing oxidative stress leading to both hepatotoxicity and nephrotoxicity. The assumption is supported by our observation of changes in oxidative biomarkers which are the indicators of tissue's ability to cope with oxidative stress [35]. There was a significant increase in MDA levels in both liver and kidney of chromium treated rats. MDA is a major oxidation product of peroxidized polyunsaturated fatty acids and an increased MDA content is an indicator of membrane lipid peroxidation [36]. Several studies have reported elevation of MDA in both kidney and liver tissues following chromium exposure.

Along with elevation of MDA, we observed decline in activities of antioxidant enzymes in chromium exposed animals, which might be due to loss of cells expressing these enzymes due to direct inhibitory actions of ROS on these enzymes. Our results revealed that sub-chronic exposure to chromium caused a statistically significant decline in both CAT and SOD in liver and kidney of exposed animals. CAT-SOD provides the first line of defense system against oxygen toxicity [37]. The decline in SOD activity may lead to massive production of superoxide anions for conversion of superoxide to water, because this dismutation reaction is catalyzed by SOD. CAT, on the other hand, is responsible for catalytic decomposition of hydrogen peroxide to molecular oxygen and water [38]. Similarly GPx and GSH are also important sensitive indictors of increased oxidative stress. GPx modifies peroxide to nontoxic hydroxyl compound to protect the cell membrane structure. GSH is normally present in millimolar concentrations in cells and is known to protect the cellular system against the toxic effects of lipid peroxidation.

Table 3: Effect of selenium (Se) and Vitamin E (Vit E) supplementation on chromium-induced changes in oxidative stress parameters in liver

\begin{tabular}{|c|c|c|c|c|}
\hline Parameters & Group I & Group II & Group III & Group IV \\
\hline CAT $\left(\mu \mathrm{mol} \mathrm{H}_{2} \mathrm{O}_{2}\right.$ consumed $/ \mathrm{min} / \mathrm{mg}$ protein & $31.533 \pm 0.127$ & $26.318 \pm 0.231 \mathrm{a}^{* *}$ & $29.893 \pm 0.3160 \mathrm{~b}^{* *} \mathrm{~d}^{* *}$ & $30.123 \pm 0.341 c^{* *} e^{* *} f^{\#}$ \\
\hline $\mathrm{SOD}(\mu \mathrm{mol} / \mathrm{mg}$ protein & $5.891 \pm 0.234$ & $4.116 \pm 0.211 \mathrm{a}^{* *}$ & $5.610 \pm 0.208 b^{\#} d^{* *}$ & $5.192 . \pm 0.209 \mathrm{c}^{\#} \mathrm{e}^{* *} \mathrm{f}^{\#}$ \\
\hline $\mathrm{GSH}(\mu \mathrm{mol} / \mathrm{mg}$ protein $)$ & $2.117 \pm 0.166$ & $1.023 \pm 0.130 \mathrm{a}^{* *}$ & $1.938 \pm 0.210 \mathrm{~b}^{* *} \mathrm{~d}^{* *}$ & $1.829 \pm 0.307 \mathrm{c}^{* *} \mathrm{e}^{* *} \mathrm{f}^{\#}$ \\
\hline GPx (Unit/mg protein) & $38.936 \pm 0.216$ & $35.130 \pm 0.249 \mathrm{a}^{* *}$ & $37.782 \pm 0.317 b^{\#} d^{* *}$ & $37.920 \pm 0.217 \mathrm{c}^{\#} \mathrm{e}^{* *} \mathrm{f}^{\#}$ \\
\hline MDA (nmol/mg protein) & $3.176 \pm 0.264$ & $4.863 \pm 0.230 \mathrm{a}^{* *}$ & $3.762 \pm 0.412 b^{\#} \mathrm{~d}^{* *}$ & $3.496 \pm 0.315 c^{\#} \mathrm{e}^{* *} \mathrm{f}^{\#}$ \\
\hline
\end{tabular}

Group I=Control group; Group II=Chromium treated group; Group III=Se- and Vit E treated group; Group IV=Chromium plus Se- and Vit E supplemented group. Values are represented as mean $\pm \mathrm{SE}$; animals $(\mathrm{n})=6$ /group. $\mathrm{a}=$ Group I versus Group II; $\mathrm{b}=$ Group I versus Group III; c=Group I versus Group IV; $\mathrm{d}=\mathrm{Group}$ II versus Group III; e=Group II versus Group IV; $\mathrm{f}=$ Group III versus Group IV; ${ }^{*}=\mathrm{p}<0.05 ;{ }^{* *}=\mathrm{p}<0.01 ;{ }^{* * *}=\mathrm{p}<0.001$, \#=Non significant. CAT: Catalase, SOD: Superoxide dismutase, GSH: Reduced glutathione, GPx: Glutathione peroxidase, MDA: Malondialdehyde

Table 4: Effect of selenium (Se) and Vitamin E (Vit E) supplementation on chromium-induced changes in oxidative stress parameters in kidney

\begin{tabular}{|c|c|c|c|c|}
\hline Parameters & Group I & Group II & Group III & Group IV \\
\hline CAT $\left(\mu \mathrm{mol} \mathrm{H}_{2} \mathrm{O}_{2}\right.$ consumed $/ \mathrm{min} / \mathrm{mg}$ protein & $18.870 \pm 0.218$ & $11.226 \pm 0.340 \mathrm{a}^{* *}$ & $16.832 \pm 0.632 b^{* *} d^{* *}$ & $16.973 \pm 0.718 \mathrm{c}^{* *} \mathrm{e}^{* *} \mathrm{f}^{*}$ \\
\hline SOD $(\mu \mathrm{mol} / \mathrm{mg}$ protein & $1.629 \pm 0.196$ & $1.241 \pm 0.149 \mathrm{a}^{* *}$ & $1.442 \pm 0.152 \mathrm{~b}^{* *} \mathrm{~d}^{* *}$ & $1.398 \pm 0.124^{* *} \mathrm{e}^{* *} \mathrm{f}^{\#}$ \\
\hline $\mathrm{GSH}(\mu \mathrm{mol} / \mathrm{mg}$ protein $)$ & $1.882 \pm 0.264$ & $1.156 \pm 0.118 \mathrm{a}^{* *}$ & $1.539 \pm 0.139 \mathrm{~b}^{* *} \mathrm{~d}^{* *}$ & $1.692 \pm 0.133 \mathrm{c}^{* *} \mathrm{e}^{* *} \mathrm{f}^{\#}$ \\
\hline GPx (Unit/mg protein) & $9.379 \pm 0.217$ & $6.835 \pm 0.426 \mathrm{a}^{* *}$ & $7.483 \pm 0.273 \mathrm{~b}^{* *} \mathrm{~d}^{* *}$ & $7.780 \pm 0.163 c^{* *} e^{*} 8 f^{\#}$ \\
\hline MDA (nmol/mg protein) & $21.621 \pm 0.148$ & $23.482 \pm 0.173 \mathrm{a}^{* *}$ & $22.791 \pm 0.221 \mathrm{~b}^{* *} \mathrm{~d}^{* *}$ & $22.259 \pm 0.173 \mathrm{c}^{* *} \mathrm{e}^{* *} \mathrm{f}^{*}$ \\
\hline
\end{tabular}

Group I=Control group; Group II=Chromium treated group; Group III=Se- and Vit E treated group; Group IV=Chromium plus Se- and Vit E supplemented group. Values are represented as mean \pm SE; animals (n)=6/group. a=Group I versus Group II; b=Group I versus Group III; c=Group I versus Group IV; $\mathrm{d}=\mathrm{Group} \mathrm{II} \mathrm{versus} \mathrm{Group} \mathrm{III;}$ e=Group II versus Group IV; f=Group III versus Group IV. ${ }^{*}$ - $<<0.05$; ${ }^{* *}$-p $<0.01$; ${ }^{* *}$ p $<0.001$; \#-non significant. CAT: Catalase, SOD: Superoxide dismutase, GSH: Reduced glutathione, GPx: Glutathione peroxidase, MDA: Malondialdehyde 
It is very important in maintaining cellular redox status and its depletion is considered as a marker of oxidative stress [39]. Oxidative stress in tissue may cause oxidative catabolic effects leading to lipid peroxidation accompanied with the depletion of tissue GSH [40]. Our results on oxidative stress parameters in liver and kidney of chromium exposed animals are supported by previous findings on heavy metal induced oxidative stress.

A significant increase in MDA level and a significant decrease in CAT-SOD system and GPx- GSH activity is a clear indication of oxidative stress, which might have caused functional and structural disruption in both liver and kidney of chromium exposed animals. This is further confirmed by our biochemical and histopathological analysis of these tissues. All these changes in biochemical, histopathological and oxidative stress parameters observed in animals exposed chronically to chromium were found to be reversed when chromium was supplemented with selenium and Vitamin $\mathrm{E}$ in combination. The choice of these two micronutrients for supplementation along with chromium was based on success of these antioxidants against various chemical induced oxidative stress [41]. It is now established that they complement each other in their function as antioxidants and prevent production of free radicals and neutralize them. Therefore, both selenium and Vitamin E have got great potential as emerging antioxidant therapy against heavy metal induced toxicity in general and against chromium in particular.

\section{CONCLUSION}

Our present study clearly demonstrated that chronic exposure to a environmentally relevant low dose of chromium can cause both hapatotoxicity and nephrotoxicity induced by oxidative stress; and both selenium and Vitamin E in combination, can mitigate the deleterious effects of chromium on liver and kidney.

\section{AUTHOR'S CONTRIBUTION}

SC, JS, and SD contributed to data accusation, analysis of parameters, data analysis, and statistical analysis. SC prepared the initial version of the manuscript with inputs from JS and SD. DC contributed to initial study design and data accusation, statistical analysis, drafted the initial version of the manuscript and contributed to its critical revision and preparation of final version in consultation with all the contributing authors.

\section{COMPETING INTEREST}

The authors declare that they have no conflicts of interest

\section{SOURCE OF FUNDING}

This work is not supported by any funding agency. The work is conducted as routine academic pursuance of contributing authors in the laboratory of the corresponding author

\section{REFERENCES}

1. Patel JG, Joshi DV, Patel BJ, Raval SH. Effect of oral administration of potassium dichromate on haematological parameters in Wistar rats (Rattus norvegicus). Indian J Vet Pathol 2013;37:215-7.

2. Shati AA. Ameliorative effect of Vitamin E on potassium dichromateinduced hepatotoxicity in rats. J King Saud Univ Sci 2014;26:181-9.

3. Bashandy SA, Amin M, Morsy F, El-Marasy S. Amelioration of the nephrotoxic effect of potassium dichromate by whey protein and/or Nigella sativa oil in male albino rats. J Appl Pharm Sci 2016;6:44-50.

4. Saha J, Choudhuri S, Choudhuri D. Effect of sub chronic exposure to chromium on hematological and biochemical parameters of male albino rats. Asian J Pharm Clin Res 2017;10:345-8.

5. Ebyl V, Kotyzoa D, Koutensky J. Comparative study of natural antioxidants-curcumin, reeratrol and melatonn in cadmium induced oxidative damage in mice. Toxicology 2006;225:150-6.

6. Balakrishnan R, Venkat CS, Kumar S, Rani MU, Srikanth MK, Boobalan G, et al. An evaluation of the protective role of $\alpha$-tocopherol on free radical induced hepatotoxicity and nephrotoxicity due to chromium in rats. Indian J Pharmacol 2013;45:490-5.
7. Kalender S, Uzun FG, Demir F, Uzunhisarcikli M, Aslanturk A. Mercuric chloride-induced testicular toxicity in rats and the protective role of sodium selenite and Vitamin E. Food Chem Toxicol 2013;55:456-62.

8. Bhattacharjee T, Choudhuri S, Choudhuri D. Oxidative stress in rat liver and kidney due to chronic exposure to a mixture of arsenic, cadmium and lead: Protective role of selenium and zinc. Asian J Pharm Clin Res 2017;10:1-7

9. Rao MV, Parekh SS, Chawla SL. Vitamin-E supplementation ameliorates chromium-and/or nickel induced oxidative stress in vivo. J Health Sci 2006;52:142-7.

10. Mohammed AA, Abd-Elwahab WA. The potential protective role of Vitamin E and selenium against sub-chronic toxicity of hexavalent chromium on the testis of adult male albino rats. Ain Shams J Forens Med Clin Toxicol 2020;34:22-33

11. Indian Council of Medical Research. Use of Animals in Scientific Research. New Delhi: Indian Council of Medical Research; 2000.

12. Adekunle AS, Adedeji AL, Oyewo EO, Adedosu OT, Omotoso AT. Hyperlipidemia induced by atherogenic diet enhanced oxidative stress in kidney and inflammatory response; An in vivo study. Asian J Nat Appl Sci 2013;2:82-93.

13. Bessey OA, Lowry OH, Brock MJ. A method for the rapid determination of alkaline phosphatise with fibecubicmillimeters of serum. J Biol Chem 1946;164:321-9.

14. Bradford MM. A rapid and sensitive method for the quantitation of microgram quantities of protein utilizing the principle of protein-dye binding. Anal Biochem 1976;72:248-54.

15. Ohkawa H, Ohishi N, Yagi K. Assay for lipid peroxides in animal tissues by thiobarbituric acid reaction. Analyt Biochem 1979;95:351-8.

16. Aebi H. Catalase in vitro. In: Colowick SP, Kaplan NO, editors. Methods in Enzymology. Vol. 105. Florida: Academic Press; 1984. p. 114-21.

17. Marklund S, Marklund G. Involvement of the superoxide anion radical in the auto oxidation of pyrogallol and convenient assay for superoxide dismutase. Eur J Biochem Biophys 1974;47:469-74.

18. Paglia DE, Valentine WN. Studies on quantitative and qualitative characterization of erythrocyte glutathione peroxidase. J Lab Clin Med 1979; $70: 158-69$

19. Ellman GL, Fiches FT. Quantitative determination of peptides by sulfhydryl groups. Arch Biochem Biophys 1959;82:70-2.

20. Banerjee S, Joshi N, Mukharjee R, Singh PK, Baxi D, Ramachandran AV. Melatonin protects against chromiu (VI) induced hepatic oxidative stress and toxicity: Duration dependent study with realistic dosage. Interdiscip Toxicol 2017;10:20-9.

21. Gilbert RK, Kenneth B, Dennis P, Samuel CK, Robert W. A randomized, double masked, placebo-controlled study of the effects of chromium picolinate supplementation on body composition: A replication and extension of previous study. Curr Ther Res 1998;59:379-88

22. Trif A, Petrovici S, Petrovici M, Dumitrescu E, Olariu L, Tulcan C, et al. Effect of potassium dichromate intake on feed intake and body weight, in female rats, Rattus norvegicus (exposure on three generations). Hum Vet Med 2010;2:32-6.

23. Zhai Q, Narbad A, Chen W. Dietary strategies for the treatment of cadmium and lead toxicity. Nutrients 2015;7:552-71.

24. Novellio E, Vieira E, Rodrigues N, Ribas B. Risk assessment of cadmium toxicity on hepatic and renal tissues of rats. Environ Res 1998;79:102-5.

25. Momo CM, Ferdinand N, Bebe NK, Marquise MN, Augustave K, Narcisse VB, et al. Oxidative effects of potassium dichromate on biochemical, hematological characteristics, and hormonal levels in rabbit doe (Oryctolagus cuniculus). Vet Sci 2019;6:30.

26. Yanardag R, Sacan OO. Combined effects of Vitamin C, Vitamin E, and sodium selenite supplementation on absolute ethanol induced injury in various organs of rats. Int J Toxicol 2007;26:513-23.

27. Yousif AS, Ahmed AA. Effects of cadmium $(\mathrm{Cd})$ and lead $(\mathrm{Pb})$ on the structure and function of thyroid gland. Afr J Environ Sci Technol 2009;3:78-85

28. Guo L, Xiao Y, Wang Y. Hexavalent chromium-induced alteration of proteomic landscape in human skin fibroblast cells. J Proteome Res 2013;5:3511-8

29. Ahmad MK, Syma S, Mahmood R. Cr (6) induces lipid peroxidation, protein oxidation and alters the activities of antioxidant enzymes in human erythrocytes. Biol Trace Elem Res 2011;144:426-35.

30. Balakrishnan R, Kumar CS, Rani MU, Kavita K, Boobalan G, Reddy AG. Evaluation of protective action of a-tocopherol in chromium-induced oxidative stress in female reproductive system of rats. J Nat Sci Biol Med 2013;4:87-93. 
31. Permenter MG, Lewis JA, Jackson DA. Exposure to nickel, chromium, or cadmium causes distinct changes in the gene expression patterns of a rat liver derived cell line. PLoS One 2011;6:e27730.

32. Yousef MI, El-Demerdash FM, Radwan FM. Sodium arsenite induced biochemical perturbations in rats: Ameliorating effect of curcumin. Food Chem Toxicol 2008;46:3506-11.

33. El-Sharaky AS, Newairy AA, Badreldeen MM, Eweda SM, Sheweita SA. Protective role of selenium against renal toxicity induced by cadmium in rats. Toxicology 2007;235:185-93.

34. Mehana EE, Raheim MA, Fazili KM. Ameliorated effects of green tea extract on lead induced liver toxicity in rats. Exp Toxicol Pathol 2012;64:291-5.

35. Mansour SA, Mossa AT, Heikal TM. Effects of methomyl on lipid peroxidation and antioxidant enzymes in rat erythrocytes: In vitro studies. Toxicol Ind Health 2009;25:557-63.

36. Kanbur M, Eraslan G, Sarica ZS, Altinordulu Ş. The effects of saw palmetto on flumethrin-induced lipid peroxidation in rats. Pestic Biochem Phys 2010;97:43-6.

37. Demir F, Uzun FG, Durak D, Kalender Y. Subacute chlorpyrifos- induced oxidative stress in rat erythrocytes and the protective effects of catechin and quercetin. Pestic Biochem Phys 2011;99:77-81.

38. Hassani S, Sepand MR, Jafari A, Jaafari J, Rezaee R, Zeinali M, et al. Protective effects of curcumin and Vitamin E against chlorpyrifosinduced lung oxidative damage. Hum Exp Toxicol 2015;34:668-76.

39. Zama D, Meraihi Z, Tebibel S, Benayssa W, Benayache F, Benayache S. Chlorpyrifos-induced oxidative stress and tissue damage in the liver, kidney, brain and fetus in pregnant rats: The protective role of the butanolic extract of Paronychia argentea L. Indian J Pharm 2007;39:145-50.

40. Garcia-Nino WR, Tapia E, Zazueta C, Zatarain-Barron ZL, HernandezPand R, Vega-Garcia CC, et al. Curcumin pretreatment prevents potassium dichromate-induced hepatotoxicity, oxidative stress, decreased respiratory complex I activity, and membrane permeability transition pore opening. Evid Based Complement Alternat Med 2013;2013:1-19.

41. Pandir D, Bekdemir FO, Doganyigit Z, Per S. Protective effect of sodium selenite and Vitamin E on LPS induced endotoxemia in rats. ACR J Nutr Growth 2017;3:19-25. 